Cornell Law Library

Scholarship@Cornell Law: A Digital Repository

Cornell Law Faculty Publications

Faculty Scholarship

$1-1-2005$

\title{
Death Sentence Rates and County Demographics: An Empirical Study
}

Theodore Eisenberg

Cornell Law School, ted-eisenberg@lawschool.cornell.edu

Follow this and additional works at: http://scholarship.law.cornell.edu/facpub

Part of the Applied Statistics Commons, Criminal Law Commons, and the Law and Society Commons

\section{Recommended Citation}

Eisenberg, Theodore, "Death Sentence Rates and County Demographics: An Empirical Study" (2005). Cornell Law Faculty Publications. Paper 344.

http://scholarship.law.cornell.edu/facpub/344

This Article is brought to you for free and open access by the Faculty Scholarship at Scholarship@Cornell Law: A Digital Repository. It has been accepted for inclusion in Cornell Law Faculty Publications by an authorized administrator of Scholarship@Cornell Law: A Digital Repository. For more information, please contact jmp8@cornell.edu. 


\title{
DEATH SENTENCE RATES AND COUNTY DEMOGRAPHICS: AN EMPIRICAL STUDY
}

\author{
Theodore Eisenberg $\dagger$
}

The number of murders in a state largely determines the size of a state's death row. ${ }^{1}$ The more murders, the larger the death row. This fundamental relation yields surprising results, including the newsworthy finding that Texas's death sentencing rate is not unusually high. ${ }^{2}$ Recent state-level research also underscores the importance of race in the demography of death row. ${ }^{3}$ Death penalty research has long emphasized race's role, and with good reason-a racial hierarchy exists in death sentence rates. ${ }^{4}$ "Black defendants who murder white victims receive death sentences at the highest rate; white defendants who murder white victims receive death sentences at the next highest rate, and black defendants who murder black victims receive death sentences at the lowest rate." ${ }^{5}$ Two race-based tendencies appear to foster this hierarchy: prosecutors' reluctance to seek or impose death in cases involving black defendants and black victims, and their eagerness to do so in cases involving black defendants and white victims. ${ }^{6}$ County-level analysis should help further illuminate death row's demography. ${ }^{7}$ Prosecutors who decide whether to seek the death pen-

$\dagger$ Henry Allen Mark Professor of Law, Cornell Law School; Bruce W. Nichols Visiting Professor of Law, Harvard Law School.

1 See John Blume, Theodore Eisenberg \& Martin T. Wells, Explaining Death Rou's Population and Racial Composition, $1 \mathrm{~J}$. EMP1RICAL Lecal Stud. 165, 186-87 (2004).

2 See id. at 173 (explaining that "Texas's reputation as a death-prone state should rest on its many murders"); Jess Bravin, Death Penalty Imposed Less Often in US South-Study, Dow Jones INT'L News, Feb. 14, 2004, at 20:33:00 (finding that Texas was "less likely to impose capital sentences than many Northern states"); Adam Liptak, Siudy Revises Texas's Standing as a Dealh Penalty Leader, N.Y. Times, Feb. 14, 2004, at A10 (noting that Texas "sentences a smaller percentage of people convicted of murder to death than the national average"); Maro Robbins, Texas Nol Really Executioners'Mecca; Study Shows State's Rate of Handing Down Death Sentences is Below National Average, SAN Antonio-Express News, Mar. 13, 2004, at 1A, available at 2004 WL 62674991.

3 See Blume et al., supra note 1, at 166 (citing David Baldus, George Woodworth, David Zuckerman, Neil Alan Weiner, Barbara Broffitt, Racial Discrimination and the Death Penally in the Post-Furman Era: An Empirical and Legal Overview, with Recent Findings from Philadelphia, 83 Connell L. Rev. 1638, 1658 \& n.61, 1659, 1660-61 \& n.69, 1662, 1742-45 (1998)).

4 See id. at 167.

5 See id.

6 See id. at $167 \&$ nn.8-9.

7 But see Andrew Gelman, James S. Liebnian, Valerie West, Alexander Kiss, A Broken System: The Persistent Patterns of Reversals of Death Sentences in the United States, $1 \mathrm{~J}$. EMPIRICAL LEGAL STUD. 209, 252-54 (2004) (reporting insignificant variation in death sentences per 
alty, and jurors who decide whether to impose it, are selected at the local, usually county, level. ${ }^{8}$ This Article explores the factors that may affect counties' contributions to death row.

Studying county-level activity may help explain the sources of the racial hierarchy: Why do black defendant-black victim cases receive by far the lowest rate of death sentences? One hypothesis is that prosecutors devalue black victims' lives and do not regard black-victim murders as seriously as white-victim murders. ${ }^{9}$ A second hypothesis, one that need not preclude the first, posits that black communities' aversion to the death penalty ${ }^{10}$ leads prosecutors to seek it less, or juries to impose it less, in minority communities. ${ }^{11}$ The first view represents a version of old-fashioned stereotypical racism. ${ }^{12}$ The second hypothesis could be regarded as democracy at work. ${ }^{13}$ Thus, communities more hostile to the death penalty may elect officials and process criminal cases in a manner that reflects local community values.

If the second hypothesis is correct, an association ought to exist between population demographics and death sentence rates. Specifically, one might expect an increase in local black population percent to be associated with a decrease in the rate at which defendants receive death sentences. A community's minority population percentage likely influences death sentence rates in two ways. First, local elected officials ought to reflect minority communities' reservations about the death penalty. ${ }^{14}$ This may lead prosecutors to seek the death penalty at a lower rate than they would in nonminority communities, assuming that other factors in a case remain constant. ${ }^{15}$ Second, when prosecutors do seek the death penalty, minority-

murder across counties and an absence of county-level effects in explaining reversal rates in capital cases).

8 See Blume et al., supra note 1, at 202-03 (explaining that in "urban communities with a strong minority presence, prosecutors may face juries that are more reluctant to impose the death penalty").

$9 \quad$ See id. at $202 \&$ n.72.

10 See, e.g., Theodore Eisenberg, Stephen P. Garvey \& Martin T. Wells, The Deadly Paradox of Capital Jurors, 74 S. CAL. L. Rev. 371, 380 (2001) [hereinafter Eisenberg et al., Deady Paradox]; Theodore Eisenberg, Stephen P. Garvey \& Martin T. Wells, Forecasting Life and Death: Juror Race, Religion, and Attitude Toward the Death Penalty, 30 J. Legal Stud. 277, 284-85 (2001) [hereinafter Eisenberg et al., Forecasting].

11 See Blume et al., supra note 1, at 202-03.

12 See id. at $167 \& \mathrm{nn} .8-9$.

13 See infra note 39 and accompanying text.

14 See Eisenberg et al., Deadly Paradox, supra note 10, at 395-96 (concluding that a failure of "democratic politics" and "democratic education" leads jurors and the general public to favor the death penalty because they do not fully understand alternative punishments).

15 See id. 
community juries might be expected to impose death sentences at a lower rate than juries in other communities. ${ }^{16}$

At least one confounding factor deserves attention. The percentage of a county's population that is black, a variable of primary interest in this study, strongly correlates with the percent of a county's murders by black defendants. Black defendant murders overwhelmingly involve black victims, ${ }^{17}$ while black defendant-black victim cases rarely lead to a death sentence. ${ }^{18}$ Thus, death sentence rates' association with counties' black population percents may reflect such rates' association with the percent of murders committed by black defendants rather than an association with counties' black population percents. One way to limit this confounding is to focus on murders involving black defendants and black victims. Variation in the rate at which black defendants receive the death penalty in black victim cases cannot be attributed to low death sentence rates in black defendantblack victim cases. A low death sentence rate in such cases would lower the baseline death sentence rate for all counties. But one cannot attribute variation in death sentence rates in black defendantblack victim cases to this low baseline.

This Article finds that, in addition to the number of murders, at least three other demographic factors influence the death sentence rate at the county level. The rate of death sentences decreases as a county's black population percent increases, as a county's per capita income increases, and as a county's homicide rate increases. ${ }^{19}$ More detailed study of black defendant-black victim cases suggests that the population percent effect is not merely an artifact of such cases comprising a higher portion of murders in minority communities. Even within the class of black defendant-black victim murder cases, the death sentence rate decreases as a county's black population percent increases. ${ }^{20}$

Part I of this Article describes the death row and homicide data sets used in this study. Part II reports two principal results. It first presents the relation between the size of death row at the county level and the county's number of murders and certain demographic factors. Second, it suggests that minority community antipathy towards

16 See Eisenberg et al., Forecasting Life, supra note 10, at 308-09 (discussing that verdicts may depend not only on the defendant's or victim's race, but also on the race of the juror).

17 From 1976 through 2000, blacks killed ninety-four percent of black homicide victims and whites killed eight-six percent of white murder victims. James ALAN Fox \& MARIanNe W. Zawitz, U.S. Dep't of Justice, Homicide Trends in the United States, available at http://www.ojp.usdoj.gov/bjs/homicide/homtrnd.htm (last revised Sept. 28, 2004).

18 See Blume et al., supra note 1, at 202-03.

19 See infra Table 2 and accompanying discussion.

20 See infra Tables 4, 5 and accompanying discussion. 
the death penalty constitutes a likely partial explanation for the low rate of black defendant-black victim cases on death row.

I

Understanding the Data at the County Level

This study employs seven data sets. Five of the data sets include information on, respectively, death row inmates in Georgia, Maryland, Pennsylvania, South Carolina, and Virginia. Some of these databases form the basis for earlier state-level death penalty research. ${ }^{21}$ The Georgia data come from the Georgia Multicounty Public Defender's Office and cover inmates sentenced to death row from 1977 through October 31, 2001. The Maryland data come from the Office of the Public Defender, Capital Defense Division, and cover inmates sentenced to death row from July 1, 1978 through October 1, 2001. The Pennsylvania data come from the Administrative Office of Pennsylvania Courts and cover inmates sentenced to death row from 1977 through June 25, 1997. The South Carolina data come from continuing study of the death penalty in South Carolina ${ }^{22}$ and cover inmates sentenced to death row from 1977 through September 30, 2001. The Virginia data come from Virginia Capital Resource Center and cover inmates sentenced to death row from 1977 through September 28, 2001. Data for all five states include the race of the defendant, race of the victim, and the county of sentencing.

A sixth data set contains information on each of the five state's murders from the FBI's Supplementary Homicide Reports (SHR). The SHR provide incident-level data about murders. For each murder, the data include the year of the offense, the race, sex, and age of the victim and of the person arrested for the offense, the county in which the offense occurred, and information concerning the nature of the murder, including whether it was committed in the course of crimes such as robbery, rape, burglary, or larceny. ${ }^{23}$ Both in terms of their availability and the reliability of reporting, murder data are anong the most reliable crime data. ${ }^{24}$

21 See Blume et al., supra note 1, at 195.

22 See id.

23 James alan Fox, Uniform Crime Reports [United States]: Supplementary HomiCIDE REPORTs, 1976-1998 [Computer file], Northeastern Univ., College of Criminal Justice [producer], Inter-university Consortium for Political \& Social Research [distributor] (ICPSR Version, Study No. 3000), 2000.

24 See Robert J. Cottrol, Hard Choices and Shifted Burdens: American Crime and American Justice at the End of the Century, 65 GEo. WAsH. L. REv. 506, 517 (1997) (book review) (noting that, as compared with other crimes, murder data appear most "reliably reported across socioeconomic, racial and other social divisions"); John J. Donohue, Understanding the Time Path of Crime, 88 J. Crim. L. \& Criminology 1423, 1425 (1998); John J. Donohue III \& Peter Siegelman, Allocating Resources Among Prisons and Social Programs in the Battle Against Crime, 27 J. Legal Stud. 1, 4 (1998). But see Michael G. Maxfield, Circumstances in Supple- 
The seventh data set contains county-level information from the United States Census Bureau, which provides information about population, income, and urbanization.

The SHR include unsolved homicides. If the data lack the offender's sex, I treat the case as unresolved, as not producing a candidate for the death sentence, and therefore eliminate it from the death sentence rate calculations. To the extent that release follows an arrest, the data overstate the number of offenders at risk for a death sentence. Since this study's primary interest centers on cross-county comparisons, rather than the absolute level of death sentence rates, erroneous murder arrests are of concern only if they vary unevenly across counties.

The SHR allow for reasonable estimates of the number of murders in each county in each of the five states. For comparison with the Georgia 1977 to 2001 death row data, this study employs the Georgia SHR data for 1976 through 1999. For comparison with the Maryland 1978 to 2001 death row data, this study uses the Maryland SHR data for 1977 through 1999. For comparison with the Pennsylvania 1977 to 1997 death row data, this study uses the Pennsylvania SHR data for 1976 through 1996. For comparison with the South Carolina 1977 to 2001 death row data, this study employs SHR data for 1976 through 1999. For comparison with the Virginia 1977 to 2001 death row data, this study uses the SHR data for 1976 through 1999. For all states studied, the difference in years studied between the SHR data and the death row data allows for lag time between arrests for murder and sentencing.

In the five states studied, blacks and whites are by far the dominant demographic groups. According to the 2000 census, more than 90 percent of each state's population consists of blacks or whites. ${ }^{25}$ For all five states, this study excludes the relatively few death sentences involving defendant-victim pairs where the race of either party is neither black nor white, and also excludes murders that the SHR data indicate involved defendants or victims other than blacks and whites. This analysis also excludes cases involving murder offenders younger

mentary Homicide Reports: Variety and Validity, 27 CrImINOLOcy 671, 675-81 (1989) (suggesting that erroneous classification of SHR data may result in over or undercounting of certain crimes, including murder). The data exclude negligent manslaughters and justifiable homicides. See Fox, supra note 23; James Alan Fox \& Jack Levin, The Will to Kill: Making Sense of Senseless Murder 172 (2001).

25 For Georgia in 2000, black and non-Hispanic whites comprised 91.3 percent of the population. For Maryland, they comprised 90.0 percent; for Pennsylvania, 94.1 percent; for South Carolina, 95.6 percent; for Virginia, 89.8 percent. See U.S. Census Bureau, 1990 Census of Population, available at http://www.census.gov/population/wava/censusdata/ 90pubs/cp-1.htm (last visited Aug. 28, 2004). The county-level demographic data used below are from the 1990 census. See U.S. Census Bureau, State \& County Quick Facts, available at http://quickfacts.census.gov/qfd (last revised July 9, 2004). 
than sixteen years of age because the Constitution prohibits capital punishment for defendants younger than sixteen at the time of the offense. ${ }^{26}$ It also excludes cases involving defendants younger than a state's death-eligibility age where that age is greater than sixteen years old. Death row data for Maryland and Pennsylvania cover shorter periods of time, causing death sentence rates for counties in those states to be slightly understated as compared to counties in the other states.

Before assessing local effects, it is important to identify the relevant geographic units that generate jury panels. The local jury pool unit is usually the county. Georgia, Maryland, Pennsylvania, and South Carolina select their juror pools at the county level. ${ }^{27}$ Maryland also has a separate trial court for Baltimore City, ${ }^{28}$ which Maryland's court rules include in the definition of county. ${ }^{29}$ Virginia has many criminal courts with jurisdiction defined at the city level. Juror lists are generated at the city level for courts with city-level jurisdiction and are generated at the county level for courts with county-wide jurisdiction. ${ }^{30}$ For convenience, this Article refers to geographical units as counties, even though relevant geographic units may in fact represent cities. For each state, the analysis matches the appropriate city-level or county-level murder data to death row data for the city or county.

Comparing counties' death row sizes and numbers of murders reveals counties' relative propensities to impose the death penalty. Table 1 reports the number of identifiable offenders, the number of death row enrollees, and the death sentence rates for the counties from the five states for which data are available. Thus, for example, 156 Georgia counties have a median death sentence rate, computed at the county level, of 2.1 death sentences per 100 murders. Maryland's

26 See Thompson v. Oklahoma, 487 U.S. 815, 836-38 (1988) (finding that the imposition of the death penalty for defendants under the age of sixteen cannot fulfill any of the goals capital punishment is intended to achieve, and would therefore constitute "'nothing more than the purposeless and needless imposition of pain and suffering'" (quoting Coker v. Georgia, 433 U.S. 584, 592 (1976))).

27 See Ga. Code Ann. \$ 15-12-40(a) (1) (2004); Md. Code Ann., Cts. \& Jud. Proc. \$ \&201 (2004); 42 Pa. Cons. Stat. Ann. \$ 4521 (a) (West 2004); S.C. Code AnN. \$§ 14-7-130, 14-17-150 (Law. Co-op. 2003).

28 Mo. Code AnN., Const. $\$ 20$ (a) (2004).

29 MD. REGs. CODE tit. 1, §202(h) (2004).

30 The relevant statute states in part:

The commissioners shall, not later than December 1 following their appointment, submit a list showing the names, addresses and, if available, the occupations of such of the inhabitants of their respective counties or cities as are well qualified under $\$ 8.01-337$ to serve as jurors and are not excluded or exempt by $\$ \$ 8.01-338$ to $8.01-341$ and $8.01-342$. Such master jury list shall be used in selecting jurors for a twelve-month period beginning on the first day of the first term of court in the calendar year next succeeding December 1. The number of persons selected for each court shall be as specified in the order appointing the commissioners.

VA. Code ANN. § 8.01-345 (Michie 2004). 
counties have a median of less than one death sentence per 100 murders. The death sentence rates for this group of five states fall somewhat below the death sentence rates of other states that permit capital punishment. ${ }^{31}$

\section{Table 1. Death Sentences and Murders, State and COUNTY Summary}

\begin{tabular}{lccccc}
\hline & $\begin{array}{c}\text { Number of } \\
\text { Death } \\
\text { Sentences }\end{array}$ & $\begin{array}{c}\text { Number of } \\
\text { Murder } \\
\text { Offenders }\end{array}$ & $\begin{array}{c}\text { Mean County- } \\
\text { Level Death } \\
\text { Sentence Rate }\end{array}$ & $\begin{array}{c}\text { Median County- } \\
\text { Level Death } \\
\text { Sentence Rate }\end{array}$ & $\begin{array}{c}\text { Number of } \\
\text { Counties/Cities } \\
\text { with Data }\end{array}$ \\
\hline Georgia & 285 & 11,251 & 0.0624 & 0.0206 & 156 \\
Maryland & 54 & 7,419 & 0.0122 & 0.0008 & 24 \\
Pennsylvania & 248 & 13,259 & 0.0205 & 0.0112 & 67 \\
South Carolina & 145 & 8,751 & 0.0175 & 0.0124 & 46 \\
Virginia & $\mathbf{1 4 3}$ & 8,741 & 0.0217 & 0 & 111 \\
\hline
\end{tabular}

Note: Death sentence rates represent the number of persons on death row from a county divided by the number of murders in the county. The data exclude the relatively few death sentences in cases involving defendant-victim pairs in which neither party is black or white. The number of murders is limited to murders involving whites and blacks in the four possible defendant-victim racial combinations. Murder data for Georgia, South Carolina, and Virginia cover the years 1976-1999; murder data for Maryland cover 1977-1999; murder data for Pennsylvania cover 1976-1996. Death sentence data for Georgia, South Carolina, and Virginia cover 1977 through most of 2001; data for Maryland cover 1978 through most of 2001, data for Pennsylvania cover 1977 through half of 1997 . Sources of data are described in the text.

Since the data contain the race of defendants and victims, one can compute a death sentence rate specific to black defendant-black victim cases and specific to the other three defendant-victim racial combinations. Such state-level statistics are reported elsewhere. ${ }^{32}$

Data for the county of Philadelphia, Pennsylvania reveal that it has by far the largest number of murders (over 7,000) and the largest number of death row enrollees (127) for the period studied. Philadelphia is most extraordinary in its dominance of the portion of black defendant-black victim death row enrollees. For the five states in this study, a total of 196 death row inmates were involved in black defendant-black victim crimes. Ninety-two of those inmates, or forty-seven percent, were from Philadelphia. In comparison, Philadelphia accounted for 5,514 of the 29,452 black defendant-black victim murders in the sample, or nineteen percent of such murders.

Philadelphia's dominance of the black defendant-black victim combination on death row does not, however, extend to other defendant-victim race combinations. Philadelphia accounted for 20 of 219 , or only nine percent, of black defendant-white victim death row enrollees, while it comprised 656 of 4,038 , or sixteen percent, of such murders. It accounted for 14 of 317 , or four percent, of white defen-

31 See Blume et al., supra note 1, at 172.

$32 I d$. at 197. 
dant-white victim enrollees although it accounted for 1,127 of 14,804, or eight percent, of such murders. Further, Philadelphia accounted for one of nineteen white defendant-black victim death row enrollees, or five percent, while it had 227 of 1,161, or twenty percent, of such murders. In sum, when compared to other locales, Philadelphia sentenced black defendant-black victim offenders to death at a vastly higher rate. Philadelphia is so strikingly different from other counties that including it in standard statistical analyses substantially alters the patterns that emerge in more than 400 other counties. Consequently, some analyses in this Article exclude Philadelphia. ${ }^{33}$

\section{I1 \\ RESULTS}

Describing the relation between a county's number of death row inmates and its number of murders and demographic factors will help put the race-related results in perspective.

\section{A. Explaining Counties' Contribution to Death Row Size}

Figure 1 shows that the relation between murders and death row size survives at the county level. Each ${ }^{\circ}$ point in the figure represents a county and connotes the size of the county's death row and its number of murders. The data "flow" from lower left to upper right, suggesting that, as a county's number of murders increascs, so does the number of individuals sentenced to death from the county. Figure 1 also shows that many counties contribute zero defendants to death row, and still others contribute only one defendant. Of the 429 counties reported here, 200 did not place a murder defendant on death row and 90 placed one defendant on death row during the approximately twenty-year period studied. Non-death-sentence counties include twenty-five counties in which no reported murder occurred during the period studied. Finally, the "P" data point in the upperright corner of Figure 1 represents Philadelphia.

The correlation between the number of death row inmates from a county and its number of murders is highly statistically significant $(r=0.83 ; p<0.0001)$, where $r$ represents the correlation coefficient. The non-normal distribution of the data, however, suggests that this correlation is probably inflated. Using the square root of the number of death row inmates from a county and the $\log$ of the number of murders in a county yields $r=0.65$ and $p<0.000 \mathrm{I}$. If one limits the sample to the 229 counties with at least one person on death row, the results after these transformations are $r=0.62$ and $p<0.0001$. In short, consistent with state-level findings, the number of murders in a geo-

33 Tables 4-6 exclude data from Philadelphia. 
Figure 1. Death Row Enrollees and Murders by County

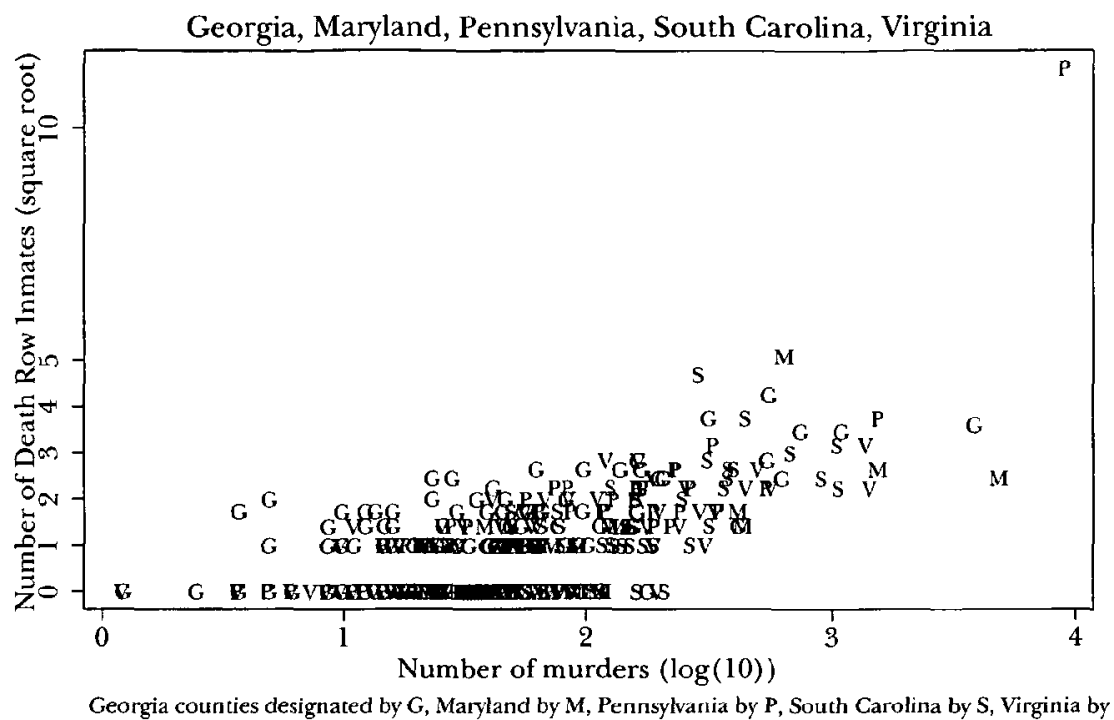

Note: For Georgia, South Carolina, and Virginia murder data cover 1976-1999; for Maryland, 1977-1999; for Pennsylvania, 1976 through 1996. For Georgia, South Carolina, and Virginia death sentence data cover 1977 through most of 2001; for Maryland, 1978 through most of 2001; for Pennsylvania, 1977 through half of 1997. Sources of data are described in text.

graphical unit (the county) is likely the single most influential factor determining the number of persons on death row due to murders in the unit.

Factors other than the number of murders also influence death row populations. State-level research suggests that variations in the legal environments, such as death penalty statutes and the degree to which political pressure on elected judges might influence death sentence rates, ${ }^{34}$ could help explain death sentence rates. Since only five states are studied here, and these factors are constant or difficult to detect across counties, this study does not address such factors. This analysis focuses instead on variations in counties' social or demographic environments and on the circumstances of the murders from which death penalty cases might be selected.

\section{Demographic Factors}

In addition to the number of murders, factors such as race, income, and urbanization may plausibly influence death sentence rates. Race effects in both seeking and obtaining the death penalty are well known. The racial composition of defendant-victim pairs, especially

34 See Blume et al., supra note 1, at 176-81. 
the race of the victim, affects capital case processing. ${ }^{35}$ At the state level, race factors are not helpful in explaining variation in death sentence rates. ${ }^{36}$ This may be because, at the state level, local, influential racial factors tend to cancel each other out or to be diluted by various state-level influences. At the county level, in the studied states, some race factors do correlate with sentencing to death row. Table 2 shows that significant correlations exist between counties' death sentencing rates and (1) the proportion of a county's murders involving black defendants and black victims, (2) the proportion of a county's murders involving white defendants and white victims, (3) the proportion of a county's murders involving victims who are strangers, (4) a county's black population percent, (5) a county's urbanization, (6) a county's black homicide rate, and (7) a county's white homicide rate. I defer discussing these race characteristics pending isolation, through factor analysis, of the extent to which factors, some of which are highly correlated, uniquely contribute to the analysis. ${ }^{37}$

Factor analysis suggests that the ten characteristics noted in Table 2 reduce to four principal factors. These are reasonably well represented hy (1) black population percent (or proportion of murders involving black defendants and black victims, which is highly correlated with black population percent), (2) the proportion of murders involving black defendants and white victims, (3) the two homicide rates (which are correlated with each other), and (4) the urbanization or income factors. Together, the four factors explain all the variance across the ten variables, with the first factor explaining about 60 percent of the variance. Regression models not reported here indicate that the black defendant-white victim proportion and the white defendant-white victim proportion are not independently helpful in explaining county death row sizes. With respect to the black defendantwhite victim proportion, this may be because, despite the death proneness of such cases, ${ }^{38}$ such interracial murders account for a small fraction of murders (eight percent according to Table 2) and the effects of such a rare phenomenon might be swamped by the other data.

35 See, e.g., Baldus et al, supra note 3 , at 1658-62, 1742-45.

36 See Blume et al., supra note 1, at 183-85; James Liebman, Jefrrey Fagan \& Valerie West, A Broken System: Error Rates in Capital Cases 1973-1995, at 88 (2000) (fig. 23) (showing little correlation between state-level death sentence rates and per capita homicide rates). The absence of significant correlation between murder rates and death sentence rates, however, should not be confused with the presence of a strong correlation between the number of murders and the number of death sentences.

37 Factor analysis seeks to find a subset of common factors from a larger set of original variables. It is "a mathematical technique for reducing a complex system of correlations into fewer dimensions." Stephen Jay Gould, The Mismeasure of Man 275 (rev. ed. 1996); see Theodore Eisenberg, Stephen P. Garvey \& Martin T. Wells, But Was He Sorry? The Role of Remorse in Capital Sentencing, 83 CORNell L. Rev. 1599, 1628 \& n.55 (1998).

38 Blume et al., supra note 1, at 197 (tbl. 8). 
Table 2. Assoclation Between County Death Sentence Rates and Murder and Population Demographics

\begin{tabular}{|c|c|c|c|c|}
\hline Murder or population characteristic & $\begin{array}{c}\text { Mean of } \\
\text { characteristic } \\
\text { for counties }\end{array}$ & $\begin{array}{l}\text { Correlation } \\
\text { with death } \\
\text { sentence rate }\end{array}$ & $\begin{array}{l}\text { Significance } \\
\text { of correlation }\end{array}$ & $\begin{array}{l}\text { Number of } \\
\text { counties }\end{array}$ \\
\hline $\begin{array}{l}\text { Proportion of murders with black } \\
\text { defendants \& white victims }\end{array}$ & .081 & .022 & .665 & 404 \\
\hline $\begin{array}{l}\text { Proportion of murders with black } \\
\text { defendants \& black victims }\end{array}$ & .596 & -.262 & .000 & 404 \\
\hline $\begin{array}{l}\text { Proportion of murders with white } \\
\text { defendants \& white victims }\end{array}$ & .299 & .257 & .000 & 404 \\
\hline $\begin{array}{l}\text { Proportion of murders with multiple } \\
\text { victims }\end{array}$ & 033 & .112 & .025 & 404 \\
\hline $\begin{array}{l}\text { Proportion of murders involving } \\
\text { victims who are strangers } \\
\text { Black population percent } \\
\text { Percent in urban areas } \\
\text { Black homicide rate } \\
\text { White homicide rate } \\
\text { Per capita income }\end{array}$ & $\begin{array}{r}.185 \\
33.3 \% \\
76.4 \% \\
.0063 \\
.0010 \\
\$ 13,443\end{array}$ & $\begin{array}{l}-.106 \\
-.263 \\
-.150 \\
-.189 \\
-.189 \\
-.058\end{array}$ & $\begin{array}{l}.033 \\
.000 \\
.003 \\
.000 \\
.000 \\
.244\end{array}$ & $\begin{array}{l}404 \\
404 \\
404 \\
400 \\
404 \\
404\end{array}$ \\
\hline
\end{tabular}

Note: Data are weighted by the number of murders in each county. Murder data for Georgia, South Carolina, and Virginia cover the years 1976-1999; murder data for Maryland cover 1977-1999; murder data for Pennsylvania cover 1976-1996. Death sentence data for Georgia, South Carolina, and Virginia cover 1977 through most of 2001; data for Maryland cover 1978 through most of 2001, data for Pennsylvania cover 1977 through half of 1997. Sources of data are described in the text. Significance levels are reported as p-values.

With respect to the effect of the black defendant-black victim proportion of murders, its high correlation with the county's black population percent requires additional analysis to try to separate the influence of these two characteristics. The first regression models reported below in Table 3 use black population percent as an explanatory variable, and models reported in subsequent tables focus specifically on black defendant-black victim cases.

\section{Other Murder Circumstances}

The SHR data include information about the circumstances of murders. One source of variation in counties' influence on death rows could be differences in the nature of murder across counties. Some murder characteristics are strong candidates for correlation with death row sizes. First, crimes involving multiple victims are on average likely to be regarded as more death-worthy than cases involving individual victims. In some states, multiple-victims is itself an aggravating circumstance supporting a death penalty. Second, cases involving strangers as victims may be regarded as especially death-worthy by prosecutors and adjudicators. But Table 2 shows no large or significant correlation between these factors and a state's death sen- 
tence rate. In fact, an inverse relation exists between death sentence rates and the proportion of murders that involve strangers. ${ }^{39}$

The homicide rate effect reported in Table 2 will be seen to persist throughout the analysis. It is, at first glance, in what some might find to be a surprising direction. Higher homicide rates are associated with lower death sentence rates. This could be because homicide rates strongly correlate with the percent of murders involving black defendants and black victims. This percent, in turn, strongly negatively correlates with death sentence rates. But, as shown below, the homicide rate effect persists in a subset of the data limited to black defendant-black victim cases.

Alternatively, the negative association may result from the legal system's limited capacity to process capital cases. Researchers suggest that the expense of capital cases and other factors limit the absolute number of death sentence cases a jurisdiction can prosecute. ${ }^{40}$ This is consistent with evidence that the number of additions to states' death rows over time varied only slightly for many years. From 1982 through 1999 , roughly the time period covered by this study, the number of defendants added each year to states' death rows in the entire United States ranged only from 266 to 326.41 At the margin, therefore, the prosecution of one capital case likely precluded the prosecution of another. If that is so, a larger number of homicides for a fixed popuIation will result in a lower death sentence rate, as Table 2 suggests, and as the models below confirm.

One caveat about the correlations in Table 2 is in order. As noted above, 200 of the 429 counties in the sample imposed no death sentences during the period studied. The presence of so many zero death rates significantly complicates detecting simple linear correlations between death sentence rates and either demographic or murder-circumstance variables. The dominance of zero death sentence rate counties and numerous possible influential factors suggest the

39 The data do not allow for case-level control of murder characteristics.

40 Ser Samifel R. Gross \& Robert Mauro, Death and Discrimination: Racial DisparITIES IN CAPITAL SENTENCING 114 (1989) (suggesting that prosecutorial discretion accounts for the limited number of death cases); LIEBMAN ET AL., supra note 36, at 106-27; Samuel R. Gross, The Romance of Revenge: Capital Punishment in America, in 13 Studies in Law, PoL. \& Soc'v 71, 78, 95 (Austin Sarat \& Susan S. Silbey eds., 1993) (arguing that financial restraints and procedural complexities limit the number of capital cases); Steve Brewer, $A$ Deadly Distinction: County Has Budget to Prosecute with a Vengeance, Houston Chron., Feb. 4, 2001 (reporting that the district attorney in Harris County, Texas tries between ten and fifteen capital cases a year, an abnormally high number, owing to his thirty million dollar budget), available at 2001 WL 2996969. The effect of restricted state resources on death sentence rates is not detectable in the relation between deatl sentence rates and states' court expenditures. See Blume et al., supra note 1, at 183-84 n.52.

41 See Blume et al., supra note 1 , at 204. Recent data indicate that the number of persons added to death row has declined substantially in the last few years. See Adam Liptak, Fewer Death Sentences Being Imposed in U.S., N.X. TimEs, Sept. 15, 2004, at Al6. 
need for more sophisticated models. To this end, regression analysis can more formally estimate the relation between the number of murders from a county and the number of defendants on death row from a county.

Table 3 reports binomial regression models ${ }^{42}$ in which the dependent variable is, for each county, the number of inmates on a state's death row. The binomial regression models control for the number of murders in each county, as well as for county-level demographic factors of interest, such as black population percent, urbanization proportion, per capita income, and homicide rates. Models 7 and 8 add dummy variables for each state, with Georgia serving as the reference category.

The coefficient on the black population percent variable is negative and statistically significant in all models. The coefficients on per capita income and the black homicide rate are also consistently, negatively, and significantly associated with the number of offenders on death row from a county. Higher income counties tend not to send offenders to death row and counties with higher black homicide rates also tend to avoid death sentences. Urbanization and the white homicide rate fail to achieve statistical significance, but the factor analysis described above indicates that most of the potential contribution of such variables to explaining death sentences is achieved by using per capita income and the black homicide rate. The correlations among the explanatory variables are reported in Appendix Table 1. The models suggest that the number of murders (as suggested by Figure 1), black population percent, income levels, and homicide rates help explain the contribution of each county to the composition of death row.

As noted above, the high correlation between the percentage of murders by blacks and the black population percent factor, as confirmed by factor analysis, ${ }^{43}$ complicates interpretation of the black population percent. Counties' contributions to death row may de-

42 Generalized linear regression models approach non-normal data with a minimum of extra complication as compared with normal linear regression. These regression models are flexible enough to include a wide range of common situations, including binomially distributed data, but at the same time allow most of the familiar ideas of normal linear regression to carry over. For a discussion of generalized linear models, see P. McCullagh \& J. A. Nelder, Generalized Linear Models 21-25 (2d cd. 1989). The dependent variables analyzed in the regressions represent the number of events of a particular type out of a certain universe of offenders. The binomial model is thus the appropriate distributional model. The models use the sandwich, often known as the robust, covariance estimator, to estimate the standard errors of the regression estimators. See Peter J. Huber, The Behavior of Maximum Likelihood Estimates Under Nonstandard Conditions, in 1 ProceEdINGS OF THE FIFTH Berkeley Symp. on Math. Stats. \& Probability 221-33 (1967). This estimator remains consistent irrespective of underlying distributional assumptions, even if the model underlying the parameter estimates is incorrect.

43 See supra note 42 and accompanying text. 


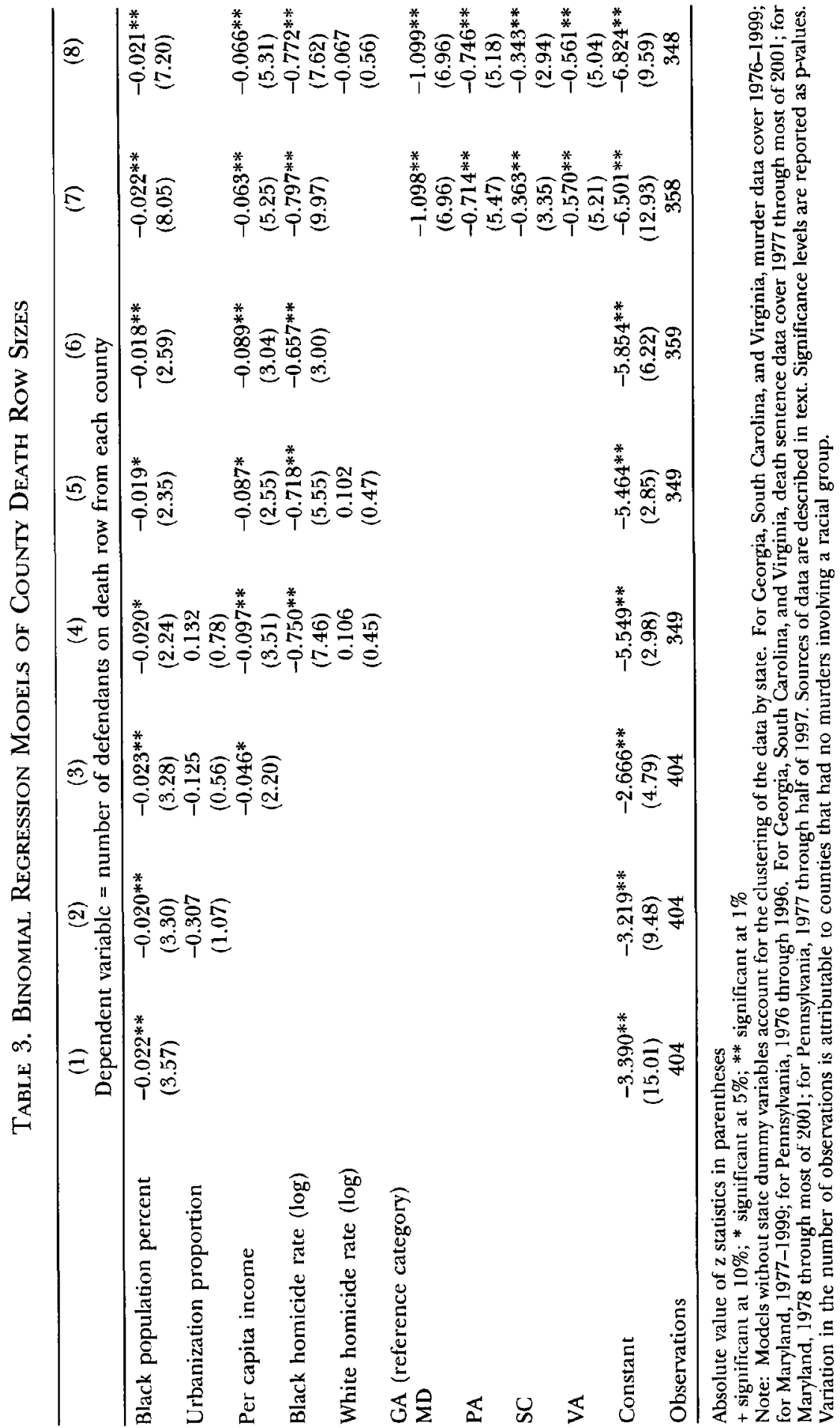


crease as a function of black population or may decrease as the proportion of black defendant-black victim cases increases. Exploring other models may isolate the effect of minority population percents.

\section{B. Exploring the Black Population Effect}

Limiting the data sample to murders involving black defendants and black victims may further isolate the effect of the black population percent. Limiting the sample in this manner eliminates the direct influence of the percent of murders involving black defendants and black victims. The restricted sample of murders becomes the universe of murders out of which the black defendant-black victim portion of death row emerges. Variation in the death sentence rate in black defendant-black victim cases should therefore come from factors outside the racial composition of this pool of murder cases. For example, if black communities are in fact more reluctant to impose death sentences, a negative association should persist between black population percent and death sentence rates in this large subset of murders.

Even a reduced murder and death row sample, however, may not exclude other explanations for this negative association. A county's black population percent may correlate with other demographic features. Detecting the hypothesized relation may be an artifact of the other correlations. Suppose that death sentence rates are negatively associated with black population percent. That may be evidence that the black population percent helps explain death sentence rates. But, since the black population percent correlates with urbanization and income, the true relation may be between these other demographic features and the death sentence rate. One needs to explore the relation between death sentence rates and black population percent while controlling for the relation of these two variables to related demographic factors.

Table 4 explores, for each defendant-victim race combination, the relation between death sentences and key demographic factors. The binomial regressions model how many murders of the specified defendant-victim race combination wind up on death row. Separate models estimate the death row population for each of the four defendant-victim racial combinations. The models control for each county's number of murders (through the use of binomial regression) of the relevant defendant-victim racial type. For black defendantblack victim cases, the inverse relation between death sentences and black population percent appears in model 1, which also accounts for other key demographic characteristics, such as homicide rates, urbanization, and income. The result persists in model 2 , which adds dummy variables for the states. In the other models, the black popula- 
tion percent has no significant relation to death sentencing for the other defendant-victim racial combinations, as shown in models 3 through 6. Note that Table 4 excludes Philadelphia County. Its high rate of death sentences in black defendant-black victim cases, as suggested earlier, would obscure the effect observed in other counties.

Table 4 suggests that a question of primary interest is, as models 1 and 2 suggest, whether the pattern of death row inmates in black defendant-black victim cases relates to the counties' black population percentages. To help illustrate the relation, Figure 2 shows that relation for the 93 counties with at least a cumulative total of 40 black defendant-black victim cases for the approximately 20 years studied.

The figure suggests three prominent results. First, despite having at least 40 black defendant-black victim cases, no death sentences were imposed in many of the counties. Second, in those counties that have non-zero death sentence rates, a negative relation exists between the death sentence rate and the black popnlation percent. Figure 2 also suggests discernable break points in the relation between death sentence rates and black population percents. Imagine a vertical line extending up from the $\mathrm{x}$-axis at the point corresponding to a black population percent of 30 percent. Only to the left of such a line does one observe a nontrivial number of county death sentence rates above 2 percent. To the right of the hypothetical line, virtually no sizeable counties have such a high death sentence rate. A similar hypothetical line at 45 percent along the $\mathrm{x}$-axis roughly divides the counties into those that have even a one percent death sentence rate and those that do not.

These break points may represent critical figures in the jury selection process. In counties with less than 30 percent (or perhaps 45 percent) black populations, it may be difficult for a critical mass of black jurors to survive the jury selection process. And a single, skeptical juror, more likely to come from the black than white popnlation, can make all the difference. A study of 53 capital trials in South Carolina revealed that a difference of even one juror reluctant to impose the death penalty can mean the difference between life and death verdicts:

If less than two-thirds of the jurors cast their first vote for death, the final verdict was always life. On the other hand, if more than threequarters cast their first vote for death, the final verdict was always death (assuming the jury does not deadlock). The final sentence is uncertain only when the percentage of jurors casting their first vote for death lies between 67 and 75 percent. In this critical range, seven of $\mathrm{I} 1$ cases resulted in a death verdict; four resulted in life. But outside this narrow zone, the final result is predictable-all depending on the distribution of life and death votes after the first ballot. In effect, the first vote is often the last. 


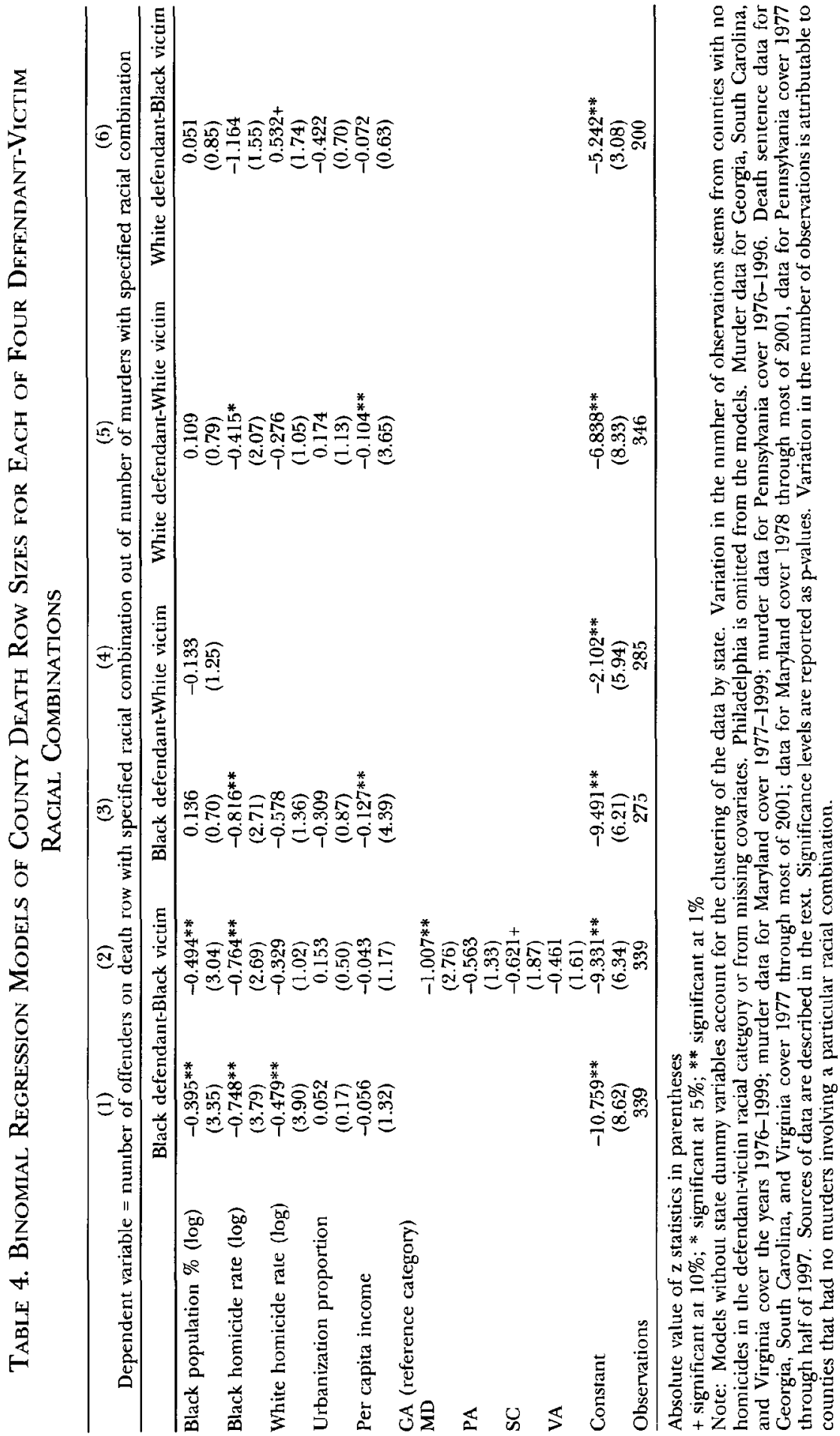


Figure 2. Death Sentence Rate and Black Population Percent

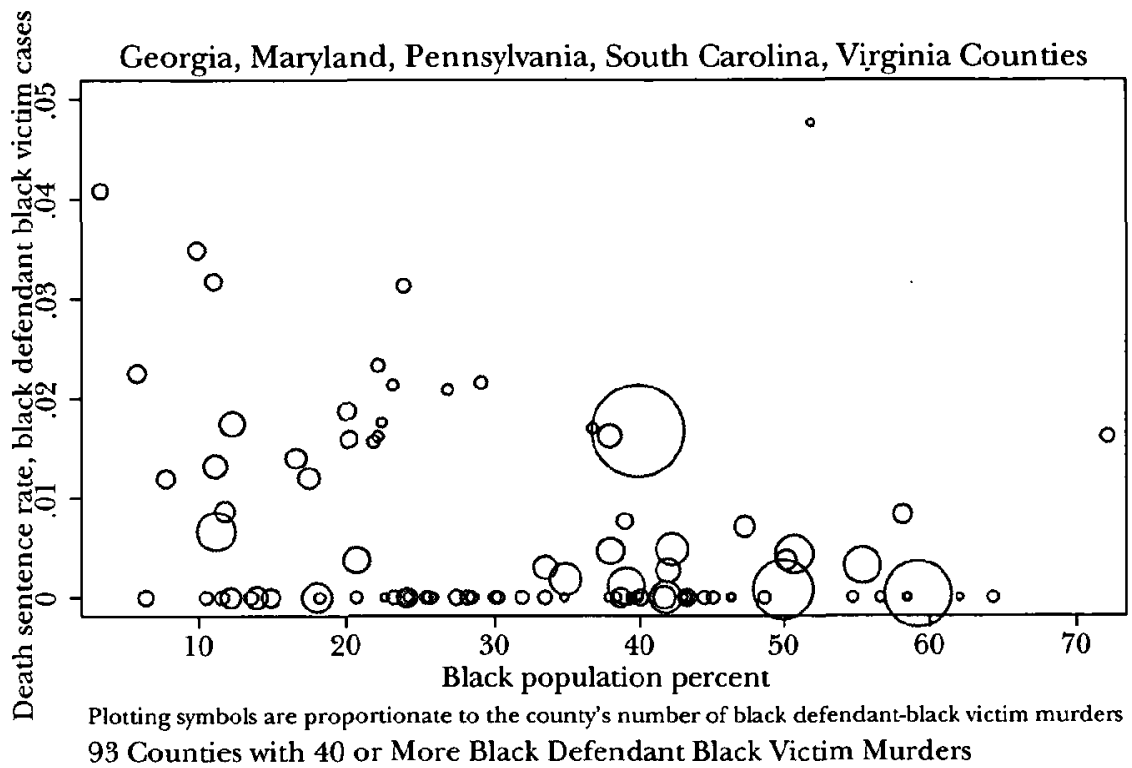

Note: For Georgia and South Carolina, murder data cover 1976-1998; for Maryland, 1977-1998; for Pennsylvania, 1976 through 1996. For Georgia and South Carolina, death sentence data cover 1977 through most of 2001; for Maryland, 1978 through most of 2001; for Pennsylvania, 1977 through half of 1997. Sources of data are described in text.

We can put these figures in an even more dramatic light: A death verdict is close to guaranteed if the prosecution can persuade at least nine of the 12 jurors to cast their first vote for death. Conversely, a life verdict is close to guaranteed if the defense can persuade at least seven jurors to vote for life or at least say they are undecided. The tipping point is juror eight. If juror eight goes with the prosecution and the jury reaches unanimity, the result will be death; if juror eight goes with the defense, the result will be life. ${ }^{44}$

The county-level population demographics represented in Figure 2 may well translate into differences in specific jury demographics. Across several juries in a county, a systematic difference of even one juror could make a significant difference in death sentence rates.

Table 5 further analyzes the relation between death sentence rates in black defendant-black victim cases and certain demographics. The table reports binomial regression models in which the dependent variable is, for each county, the number of black defendants on death row who were convicted of murdering black victims. The models control for each county's number of murders through the use of binomial

44 See Eisenberg et al., Forecasting, supra note 10, at 303-04 (citations omitted). 
regression, and also control for four county-level demographic factors of interest: black population percent, urbanization percent, per capita income, and homicide rates. The full model reported in model 1 of Table 4 yields results consistent with the models in Table 5 that employ different combinations of the explanatory variables. The coefficient on the black population percent variable is statistically significant in all the models.

One concern about the models employed is that the dependent variable in the black defendant-black victim cases often takes on a value of zero. Of the 349 counties in the study with a black defendantblack victim murder, 288 have no black defendant on death row convicted of murdering a black victim. Two other sets of models, not reported here, confirm the reported results. First, Table 5's binomial regression models were run on a sample that was limited to counties with at least one death row inmate for a black defendant-black victim case. That sample, consisting of 61 counties, yielded a significant coefficient on the black population percent variable for all models except model 3. In model 3, the coefficient was negative but insignificant. Model 3 may be especially vulnerable to multicollinearity because it includes both black and white homicide rates, which are highly correlated. ${ }^{45}$ Second, zero-inflated binomial regression models using the Table 5 covariates yielded a significant or nearsignificant black population coefficient in all models except two, which failed to converge.

Table 6 explores the evidence separately for each state. Because the number of observations substantially decreases at the state level, the models include only the three most prominent variables from $\mathrm{Ta}$ ble 5: black population percent, black homicide rate, and urbanization proportion. In all models except one Virginia model, the coefficient for black population percent is negative. In all but one Maryland model and the Virginia models, the coefficient is statistically significant. In the Maryland model that also includes the black homicide rate, the coefficient is not statistically significant and in the Virginia model that includes the black homicide rate, the coefficient is not negative. This may be due to substantial multicollinearity between the black population percent (log) and the black homicide rate (log) variables in both states. In Maryland, the correlation is $r=0.69$ $(\mathrm{p}=0.0003)$; in Virginia, the correlation is $\mathrm{r}=0.58(\mathrm{p}<.000 \mathrm{I}) .{ }^{46}$

Evidence from Tables 4, 5, and 6 is consistent with black communities' antipathy toward the death penalty, ${ }^{47}$ partially explaining the

\footnotetext{
45 See Appendix Table 1.

46 These correlations are computed using weighting by the number of black defendant-black victim cases in a county.

47 See Blume et al., supra note 1, at 202-03.
} 


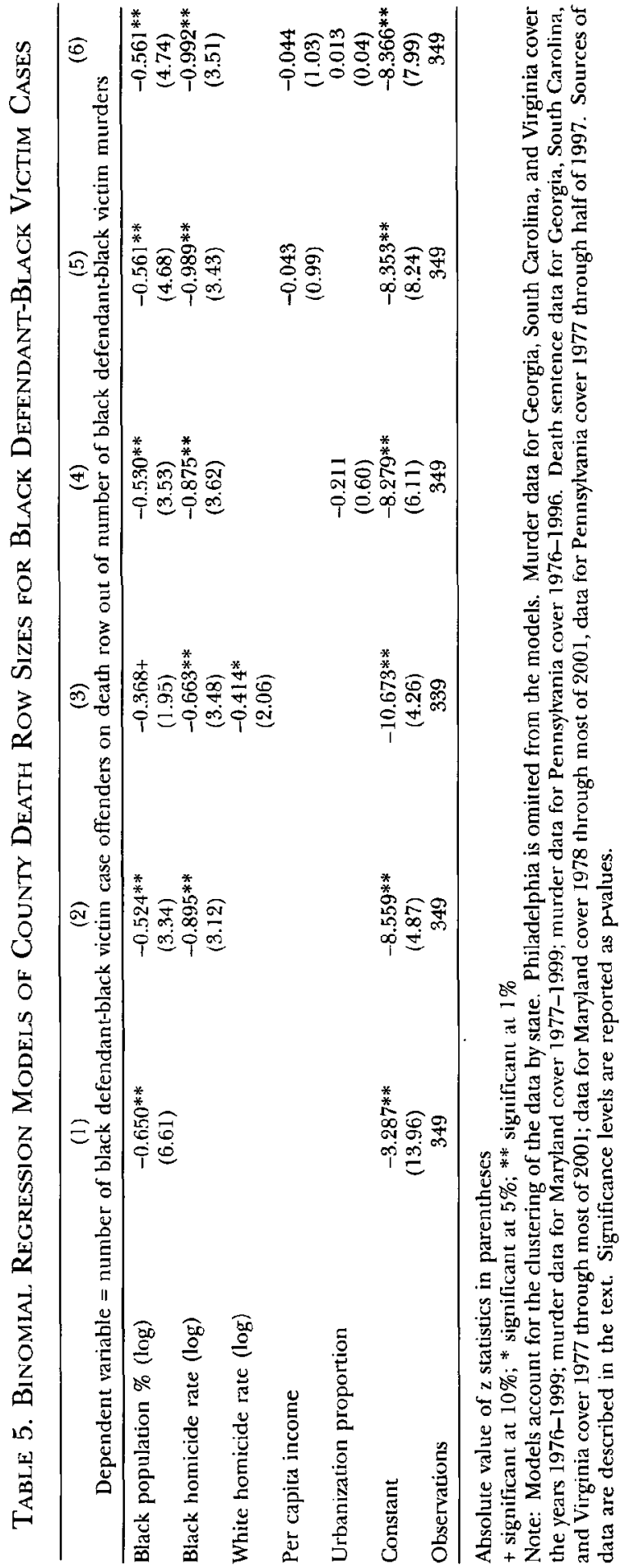




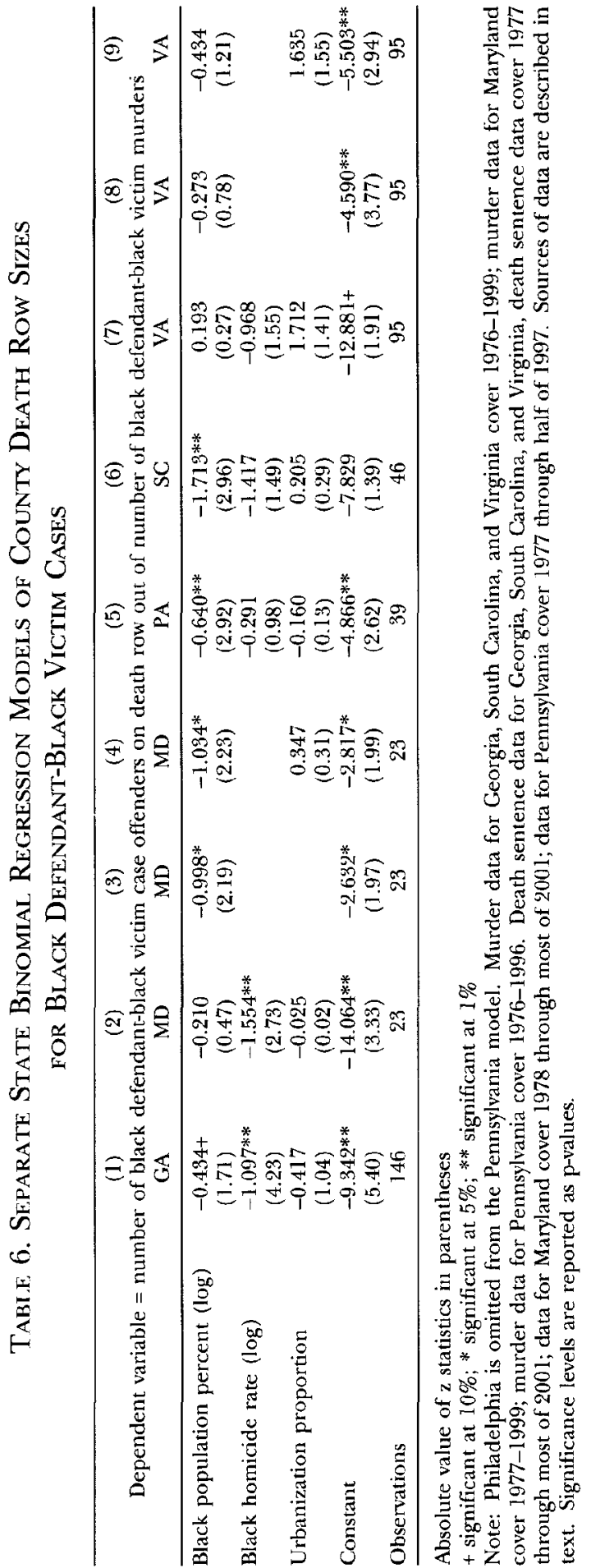


low death sentence rates in black defendant-black victim cases. One should not regard the evidence as conclusive, however, because of at least two factors. First, the results are not statistically significant or fully consistent across all five states studied. Second, high correlations between county-level demographic variables, such as race, poverty rates, and homicide rates, make it difficult to be certain that other demographic factors do not contribute to the result. Demographic analysis can be sensitive to the particular measures chosen. ${ }^{48}$

Nevertheless, the results provide some evidence that, as the black population percent increases, the rate at which death sentences are imposed decreases. Since the sample in Tables 5 and 6 is limited to black defendant-black victim cases, the effect is not an artifact of black defendant-black victim murders dominating in black communities. Communities with larger black population percents tend to impose death sentences at lower rates in black defendant-black victim cases than do communities with lower percents. Given minority suspicions about the death penalty, a plausible reason for this result is that prosecutors in minority communities tend to seek death at a lower rate, or juries in minority communities tend to impose it at a lower rate, or both.

\section{Alternative Explanations and Discussion}

Prosecutor and jury behavior are not the only possible explanation of the racial demographic effect. The "black-life-is-cheaper" theory could be a contributing factor if, regardless of community preference, prosecutors value black victims' lives less highly as counties' black population percent increases. The increased devaluing of life would then be a force driving death sentence rates down, and community preferences would play less of a role.

In addition, variables specific to murders that the models do not account for could affect the results. For example, it may be that, as a group, black defendant-black victim murders in minority communities are less death-worthy as the black population percent increases. Limited efforts, noted above, to control for two crime-specific variablescases with victims as strangers and cases with multiple victims-do not materially affect the results reported here.

One question raised by Table 4 is why the black population percent effect only emerges significantly in black defendant-black victim cases. The answer may differ for different defendant-victim race combinations. For combinations with white defendants, the hypothesized

48 Compare Theodore Eisenberg \& Martin T. Wells, Trial Outcomes and Demographics: Is There a Bronx Effect?, 80 TEx. L. REv. 1839, 1839-40 (2002), with Eric Helland \& Alexander Tabarrok, Race, Poverty, and American Tort Awards: Evidence from Three Data Sets, $32 \mathrm{~J}$. LEGAL STUD. 27, 52 (2003). 
mechanism of the population effect may suggest that no effect should be expected. The black community's well-established reservations about the death penalty do not stem from a differential moral aversion to punishing for murder. Rather, they likely stem from deep suspicions about the fairness of the criminal justice system. If the minority community's aversion to capital punishment stems from race-specific concerns, one might expect a black population effect only in cases involving black defendants. So the fact that Table 4's results show no effect in white-defendant cases is not inconsistent with the causal mechanism hypothesized to be driving the effect in black defendant-black victim cases.

The question then emerges as to why no population effect is detected in black defendant-white victim cases, as reported in Table 4's model 3. The short answer is that the effect does exist, although less robustly than in the much larger population of black defendant-black victim cases. Table 4's model 4 shows a modest population effect in black defendant-white victim cases in a simple model using only black population percent as an explanatory variable. The effect is not robust to controls for other demographic factors included in model 2. Multicollinearity across the explanatory variables, plus the relative scarcity of black defendant-white victim cases could explain the volatility of the population effect in such cases. For example, the correlation between black population percent $(\log )$ and black homicide rate $(\log )$ is $0.40(\mathrm{p}<0.0001) .49$

Figure 3 provides further insight into the black defendant-white victim case category. It includes the 78 counties in which there were at least ten black defendant-white victim homicides during the period studied. Those counties reporting the most activity in this class of cases illustrate a distinct correlation between black population percent and death sentence rates. As the black population percent increases, the death sentence rate significantly decreases $(r=-0.28$; $\mathrm{p}=0.014) .{ }^{50}$ Consistent with Figure 2, the results of Figure 3 also suggest that a black population percentage of about 30 percent may represent a critical break point in the racial composition of individual juries.

The black population effect is less robust in black defendantwhite victim cases than in black defendant-black victim cases, but it likely persists. Indeed, in the 78 counties with ten or more black defendant-white victim cases, the correlation between black population percent and the black defendant-black victim case death sentence rate

49 This correlation is computed using weighting by the number of black defendantwhite victim cases in a county.

50 This correlation represents a computation weighted by the number of black defendant-white victim cases in a county. 
Figure 3. Death Sentence Rate and Black Population Percent

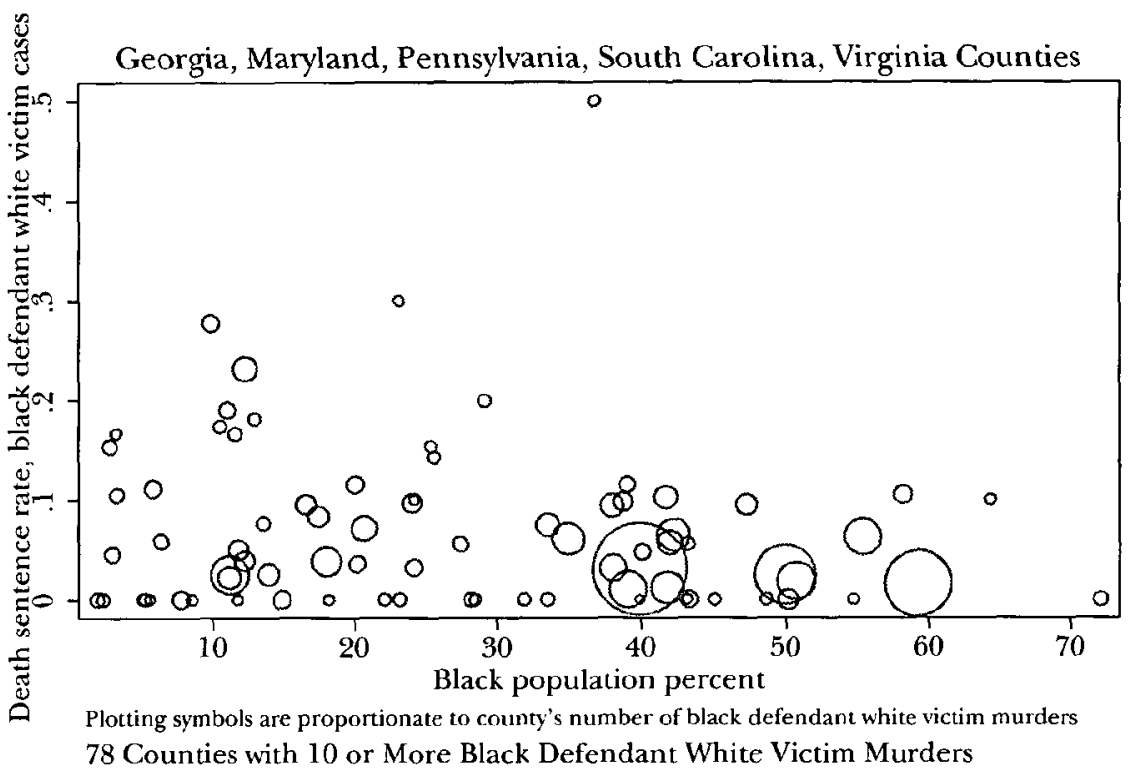

Note: For Georgia and South Carolina, murder data cover 1976-1998; for Maryland, 1977-1998; for Pennsylvania, 1976 through 1996. For Georgia and South Carolina, death sentence data cover 1977 through most of 2001; for Maryland, 1978 through most of 2001; for Pennsylvania, 1977 through half of 1997. Sources of data are described in text.

$(\mathrm{r}=-0.23 ; \mathrm{p}=0.055)$ is slightly weaker than the correlation between black population percent and the black defendant-white victim case death sentence rate. Whatever one makes of the insignificance of the black population percent coefficient in Table 4's models 3 and 4 , it does not appear to be firm evidence that no black population effect exists.

\section{CONCLUSION}

As in the case of states, the number of murders in smaller geographic units substantially influences the size of counties' contributions to death rows. Demographic factors such as race, income, and homicide rates also help to explain the composition of death row populations. The influence of some of these factors could not be detected at the state level because heterogeneous demographic characteristics within states tend to obscure such effects. The death sentence rate in black defendant-black victim homicides decreases as the black population percent increases. This suggests that minority community skepticism about the justness of the death penalty is a contributing factor to low death sentence rates in black defendant-black victim cases. 